\title{
GLACIOLOGICAL LITERATURE
}

THIs selected list of glaciological literature has been prepared by J. W. Glen with the assistance of T. H. Ellison, W. B. Harland, Miss D. M. Johnson, W. H. Ward, G. T. Warwick and the Staff of the Scott Polar Research Institute. Its field is the scientific study of snow and ice and of their effects on the earth; for the literature on polar expeditions, and also on the "applied" aspects of glaciology, such as snow ploughs, readers should consult the bibliographies in each issue of the Polar Record. For Russian material the system of transliteration used is that agreed by the U.S. Board on Geographic Names and the Permanent Committee on Geographical Names for British Official Use in 1947 . Readers can greatly assist by sending reprints of their publications to the Society, or by informing Dr. Glen of publications of glaciological interest.

\section{General glaciology}

Barrera Valdebentto, H. Bibliografia glaciológica para Chile. Boletín Bibliográfico de Geofísica y Oceanografia Americanas, Parte Geofísica, Vol. I, 1958, p. 137-40. [Selective bibliography.]

[Bouché, A., comp.] Terre Adélie [et] Groenland 1947-1955: bibliographie. [Paris, Arthaud, 1956.] [ii], 5 I p. (Expéditions Polaires Françaises, Missions Paul-Émile Victor.) [Bibliography of Greenland and Terre Adélie. Includes publications of Expéditions Polaires Françaises and related material. Films listed in Annexe 3.]

Dolgushin, L. D. Mezhdunarodnyy simpozium po fizike dvizheniya l'da v lednikakh [International symposium on the physics of ice movement in glaciers]. Izvestiya Akademii Nauk SSSR. Seriya Geograficheskaya [News of the Academy of Sciences of the U.S.S.R. Geographical Series], 1959, No. 1, p. 141-45. [Chamonix, September 1958.]

[Expeditions: Arctic.] [Konferencja poświenconej omówieniu wstępnych wyników Polskiej Wyprawy na Spitsbergen. Conference devoted to discussion of the preliminary results of the Polish Expedition to Spitsbergen]. Przeglad Geofizyczny [Geophysical Review], Rocznik 3(1 I), Zeszyt 2, 1958, p. 79-1 98. [Conference of Komisję Międzynarodowego Roku Geofizycznego 1957-58 przy Prezydium Polskiej Akademii Nauk devoted to preliminary results of the Polish I.G.Y. expedition in summer 1957 to southern Vestspitsbergen. Includes papers by A. Kosiba on glaciology, A. Jahn and S. Szczepankiewicz, and J. Dylik on periglacial morphology, $\mathrm{T}$. Klatka on stone stripes and K. Birkenmajer on isostasy. English summaries to some papers.]

Glen, J. W. Physics of ice movement. Nature, Vol. 182, No. 4649, i958, p. 1 $560-62$. [Report of Chamonix symposium, September I958.]

Hamilton, Richard A., ed. Venture to the Arctic. Harmondsworth, Penguin Books, 1958. xiv, 15-283 p. (Pelican Books, A432.) [Scientific results of British North Greenland Expedition, 1952-54, contributed by specialists.]

[INTERNATIONAL Geophysical Year, I 957-58.] Preliminary reports of the Antarctic and northern hemisphere glaciology programs. New York, American Geographical Society, I.G.Y. World Data Center A, Glaciology, I958. [217] p. (I.G.Y. Glaciological Report Series, No. I.)

Lorenzo, J. L. Glaciologia Mexicana. Boletín Bibliográfico de Geofísica y Oceanografia Americanas, Parte Geofísica, Vol. I, 1958, p. 131-36. [Short history of glaciology in Mexico and full bibliography.]

\section{Glaciological instruments and methods}

Амвасн, W. Zur Bestimmung des Schmelzwassergehaltes des Schnees durch dielektrische Messungen. Zeitschrift für Gletscherkunde und Glazialgeologie, Bd. 4, Ht. I-2, 1958, p. I-8. [Method for determining water content in snow depending on measurement of dielectric constant. English summary p. 8.]

Lavrov, V. V. Modelirovaniye l'da [Making models of ice]. Problemy Arktiki [Problems of the Arctic], 1957, Vyp. 2, p. $185-9 \mathrm{I}$. [Laboratory method of making floating ice for use in experiments with small scale models, such as tank tests for ships.]

\section{PHYsics OF ICE}

BAss, R. A theoretical analysis of the mechanical relaxation of single-crystalline ice. Proceedings of the Royal Society, Ser. A, Vol. 247, No. 1251, 1958, p. 462-64. [Summary of assumptions made and results found.]

Butkovich, T. R. Recommended standards for small-scale ice strength tests. Transactions of the Engineering Institute of Canada, Vol. 2, No. 3, 1958, p. I 12-15. [Suggestions on suitable small scale tests to find values of compressive, tensile, flexural and shear strength of ice for use in engineering applications.]

Butкovich, T. R. Thermal expansion of ice. Fournal of Applied Physics, Vol. 3o, No. 3, 1959, p. 350-53. [Measurements on single crystals and polycrystalline ice.]

Eigen, M., and DE MAEYer, L. Self-dissociation and protonic charge transport in water and ice. Proceedings of the Royal Society, Ser. A, Vol. 247, No. 1251, 1958, p. 505-33. [Review of experiments, results and theories of proton movement. Comparison between protons in ice and electrons in semiconductors.]

FRANK, H. S. Covalency in the hydrogen bond and the properties of water and ice. Proceedings of the Royal Society, Ser. A, Vol. 247, No. 1251, 1958, p. 481-92. [Theoretical discussion of coordinated bond changes in water and ice.]

Gold, L. W. Some observations on the dependence of strain on stress for ice. Canadian Fournal of Physics, Vol. $3^{6}$, No. 10, 1958, p. 1265-75. [Laboratory tests indicate two sources of strain, grain deformation and slip at grain boundaries.]

GRÄNICHER, H. Lattice disorder and physical properties connected with the hydrogen arrangement in ice crystals. Proceedings of the Royal Society, Ser. A, Vol. 247, No. 1251, 1958, p. 453-6r. [Evidence of hydrogen arrangement from electric, magnetic, mechanical and diffusional properties of ice. Theory of lattice imperfections in ice.]

Hällström, M. Af. Thermodynamische Studie zum System Eis-unterkühltes Wasser. Annales Academiae Scientiarum Fennicae, Ser. A, 2, No. 82, 1957, p. 1-25. [Theoretical calculation of thermodynamic data for the system ice-supercooled water-water vapour.] 
Hallett, J., and Mason, B. J. The influence of temperature and supersaturation on the habit of ice crystals grown from the vapour. Proceedings of the Royal Society, Ser. A, Vol. 247, No. 1251, 1958, p. 440-53. [Experimental results.]

Isono, K. Mode of growth of ice crystals in air and other gases. Nature, Vol. r82, No. 4644, 1958, p. $1221-22$. [Mode of crystal growth in various gases depends on rate of diffusion of water vapour through gases.]

Langham, E. J., and Mason, B. J. The heterogeneous and homogeneous nucleation of supercooled water. Proceedings of the Royal Society, Ser. A, Vol. 247, No. I25I, I958, p. 493-504. [Experimental results.]

Lonsdale, Dame K. The structure of ice. Proceedings of the Royal Society, Ser. A, Vol. 247, No. 1251, 1958, p. 42434. [Survey of experimental evidence on the structure of hexagonal, cubic and amorphous forms of ice.]

Mason, B. J., and Maybank, J. Ice nucleating properties of some natural mineral dusts. Quarterly Fournal of the Royal Meteorological Society, Vol. 84, No. 36r, 1958, p. 235-41. [Experiments to show effectiveness, which increases if particles have once acted as ice nuclei.]

Ockman, N., and Sutherland, G. B. B. M. Infra-red and Raman spectra of single crystals of ice. Proceedings of the Royal Society, Ser. A, Vol. 247, No. 1251, 1958, p. 434-40. [Experimental data briefly described and used to discuss proposed molecular structures.]

Powell, R. W. Preliminary measurements of the thermal conductivity and expansion of ice. Proceedings of the Royal Society, Ser. A, Vol. 247, No. 1251, 1958, p. 464-66.

Raraty, L. E., and TABor, D. The adhesion and strength properties of ice. Proceedings of the Royal Society, Ser. A, Vol. 245, No. 1241, r 958, p. 184-201. [Experiments on adhesion of ice to clean and contaminated metals and to polymers, and friction on these surfaces. Methods for de-icing suggested.]

Steinemann, Ad. Dielektrische Eigenschaften von Eiskristallen. II. Teil. Dielektrische Untersuchungen an Eiskristallen mit eingelagerten Fremdatomen. Helvetica Physica Acta, Vol. 30, Fasc. 7, 1957, p. 581-6ro. [Dielectric properties of ice crystals, both pure and with fluorine impurity, measured as function of frequency, temperature, impurity concentration, crystal age and dimensions. Interpretation of results. English summary.]

Steinemann, Ad., and Gränicher, H. Dielektrische Eigenschaften von Eiskristallen. I. Teil. Dynamische Theorie der Dielektrizitätskonstante. Helvetica Physica Acta, Vol. 30, Fasc. 7, 1957, p. 553-80. [Theory of molecular processes giving rise to dielectric properties of ice.]

TAвAta, T. A measurement of visco-elastic constants of sea ice. Fournal of the Oceanographical Society of Japan, Vol. i I, No. 4, r 955, p. 185-89. (Contributions from the Institute of Low Temperature Science, No. 282.) [Results of measurements on Okhotsk sea coast of Hokkaido, I 948, 1950, 1955.]

Vick, F. A. The physics of water and ice. Science Progress, Vol. 46, No. 184, 1958, p. 646-53. [Review in "Recent rdvances in science" series.]

\section{LAND ice. Glaciers. Ice shelves}

Coachman, L. K., and others. Gas loss from a temperate glacier, by L. K. Coachman, T. Enns, and P. F. Scholander. Tellus, Vol. 10, No. 4, 1958, p. 493-95.

Coachman, L. K., and others. Gases in glaciers, by L. K. Coachman, E. Hemmingsen, P. F. Scholander, T. Enns and H. de Vries. Science, Vol. 127, No. 3309, 1958, p. 1288-89. [Analysis of gas from bubbles in glacier ice and interpretation. Also includes age determination based on $\mathrm{C}^{14}$ analysis of $\mathrm{CO}_{2}$ content of bubbles.]

Corbel, J. Aspects régionaux de l'inlandsis groenlandais. Norois, $5^{\mathrm{e}}$ An., No. 19, 1958, p. 241-66. [Discussion of date of formation and present regime of Greenland Ice Sheet shows marked differences between north and south.]

Dineley, D. L., and Garretr, P. A. Whale remains in glacier ice. Nature, Vol. i83, No. 4656, I959, p. 272. [Found in ice-cored moraine of Sveabreen, Ekmanfjord, Vestspitsbergen, r 958.]

Dolgushin, L. D. Glyatsiologicheskiye nablyudeniya v Antarktide [Glaciological observations in Antarctica]. Izvestiya Akademii Nauk SSSR. Seriya Geograficheskaya [News of the Academy of Sciences of the U.S.S.R. Geographical Series], 1958, No. 6, p. 16-25. [Ice features in "Mirnyy" area, Australian Antarctic Territory, and outline of Soviet work on them, r956-57.]

Elliston, G. R. A study of the ogives on some of the outlet glaciers of Öræfajökull. Fökull, Ár 7, I957, p. $26-32$. [Based on work of Cambridge South-east Iceland Expedition, I957.]

Epstern, S., and Sharp, R. P. Oxygen-isotope variations in the Malaspina and Saskatchewan Glaciers. Fournal of Geology, Vol. 67, No. 1, 1959, p. 88-102. [Interpretation of variations and their use to identify origin of ice.]

FIELD, W. O., jr., and others, comp. Atlas of mountain glaciers in the northern hemisphere. U.S. Army. Headquarters Quartermaster Research and Engineering Command. Technical Report EP-92, I958, vi, [59] p., maps. [Forty-eight distribution maps. Differentiation is made between large, known glaciers and small glaciers reported but not reliably mapped.]

Förtsch, O., and VIDAL, H. Seismo-glaziologische Studien an einem Gletscherfleck (Brandner Gletscher im Rätikon). Zeitschrift für Gletscherkunde und Glazialgeologie, Bd. 4, Ht. I-2, I 958, p. 35-45. [Determination of velocity of longitudinal seismic waves in firn, thickness, and bed topography of little firn patch.]

Förtsch, O., and Vidal, H. Die seismische Vermessung des Grossen Gurgler Ferners in den Ötztaler Alpen im Spätsommer 1956. Gerlands Beiträge zur Geophysik, Bd. 67, Ht. 1, 1958, p. I-30. [Seismic measurements on the Grosse Gurgler Gletscher in Ötztal Alps.]

Fristrup, B. Grønlands indlandsis. Naturens Verden, 1958, April, p. 97-1 12. [Greenland ice sheet and historical summary of its study.]

Gerasimov, V. A. Ledniki basseyna Bayankola na severe uzla Khan-Tengri [Glaciers of the basin of the Bayankol in the north of the Khan-Tengri massif]. Voprosy Geografii Kazakhstana [Questions of the Geography of Kazakhstan], Vyp. 3, 1959, p. 195-214.

Goodspeed, M. J. Preliminary report on measurements of ice thickness on the antarctic ice cap by seismic and 
gravimetric methods. Australia. Dept. of National Development. Bureau of Mineral Resources, Geology and Geophysics, Records, No. 40, 1958, iii, [33] leaves. [1957-58. MacRobertson Land. Methods and preliminary results.]

HATTERSLEY-SMith, G., and Grant, F. S. Glaciological work on "Operation Hazen", northern Ellesmere Island, 1957. Canadian Alpine Fournal, Vol. 4I, 1958, p. 89-91. [Regime, temperature and movement studies by G. Hattersley-Smith; geophysical work by F. S. Grant.]

Heinsheimer, G. J. Zur Hydrologie und Glaziologie des Lago Argentino und Ventisquero Moreno. III. Zeitschrift für Gletscherkunde und Glazialgeologie, Bd. 4, Ht. I-2, I958, p. 61-72. [Ventisquero Moreno advanced and blocked Canal de los Témpanos for period of 26 months. Observations on outflow. English and Spanish abstracts p. 6r-62.]

HofmanN, W. Der Vorstoss des Nisqually-Gletschers am Mt. Rainier, USA, von 1952 bis 1956. Zeitschrift für Gletscherkunde und Glazialgeologie, Bd. 4, Ht. I-2, 1958, p. 47-6o. [Photogrammetric surveys in $195^{2}$ and $195^{6}$ allow variations in ice thickness and ice velocity of this advancing glacier to be determined.]

HoFmANN, W. Bestimmung von Gletschergeschwindigkeiten aus Luftbildern. Bildmessung und Luftbildwesen, 1958, Ht. 3, p. 71-88. [Method of determining ice velocity using only aerial photographs and without constructing separate maps. Application to Kangigdleq and Sigssortartoq, Umanak Fjord, West Greenland.]

HoFmanN, W. Lagemessungen bei der Internationalen Glaziologischen Grönland-Expedition (EGIG) 1959. Zeitschrift für Vermessungswesen, Jahrg. 83, Ht. 7, 1958, p. 216-22. [Position measurement surveys during International Glaciological Greenland Expedition, 1959.]

Jen MeI-Ngo. The glaciation of Yulungshan, Yunnan, China. Erdkunde, Bd. 12, Ht. 4, 1958, p. 308-13. [Description of glaciers and Quaternary glaciation in Yulungshan, north-west Yunnan, China.]

KAPITSA, A. P. Dinamika krayevoy chasti lednikovogo pokrova Antarktidy v rayone rabot Sovetskoy Antarkticheskoy Ekspeditsii 1955-1957.gg. [Dynamics of the outer edge of the ice cover of Antarctica in the region of work of the Soviet Antarctic Expedition, 1955-57]. Vestnik Moskovskogo Universiteta [Messenger of Moscow University], 1958, No. 1, p. 209-20. [Australian Antarctic Territory. Thickness and movements of ice sheet and ice shelf.]

Kick, W. An Nanga-Parbat-Gletschern 1958. Mitteilungen des Deutschen Alpenvereins, 1o Jahrg., Ht. I2, I958, p. 194-96. [Glaciers in Nanga Parbat district have receded more or less as have those in Alps.]

KLEBelsBerg, R. von. Von der Vergletscherung des Kuh-i-Sawalan $(4821 \mathrm{~m}$.), Nordwest-Persien. Zeitschrift für Gletscherkunde und Glazialgeologie, Bd. 4, Ht. 1-2, 1958, p. I 19. [Short note about 4 photographs illustrating glacierization of this mountain in north-west Persia visited by mountaineering expedition in 1955.]

LACHAPELLE, E. Annual mass and energy exchange on the Blue Glacier. Fournal of Geophysical Research, Vol. 64, No. 4, 1959, p. 443-49. [Results of detailed study of mass and energy budget of glacier in north-west U.S.A.]

Lliboutry, L. Ondes cinématiques sur un glacier et glissement sur le lit. Comptes Rendus Hebdomadaires des Séances de l'Académie des Sciences, Tom. 247 , No. 1, 1958, p. I14-16. [Theory of propagation of waves down a glacier which is slipping on its bed.]

Lliboutry, L. Frottement sur le lit et mouvement par saccades d'un glacier. Comptes Rendus Hebdomadaires des Séances de l'Académie des Sciences, Tom. 247, No. 2, 1958, p. 228-30. [Explanation of jerky movement of glaciers in terms of difference between static and dynamic friction of glacier on its bed.]

Lliboutray, L. Contribution à la théorie du frottement du glacier sur son lit. Comptes Rendus Hebdomadaires des Séances de l'Académie des Sciences, Tom. 247, No. 3, 1958, p. 318-20. [Theory of slip of glacier on its bed.]

Lliboutry, L. La mécanique du glacier dans le modèle du plastique parfait. Fournal de Physique et le Radium, Tom. 19, No. 8-9, 1958, p. 55 S-56S. [Consideration of second-order terms in solution of equation of perfectly plastic glacier.]

MAKAREVICH, K. G. Osnovnyye osobennosti sovremennogo oledeneniya basseyna Lepsy v Dzhungarskom Alatau [Main features of present ice cover of the basin of the Lepsa in the Dzhungarskiy Alatau]. Voprosy Geografii Kazakhstana [Questions of the Geography of Kazakhstan], Vyp. 3, 1959, p. 176-94.

MALYKH, M. I. Sovremennoye oledeneniye Koryakskoy gornoy sistemy [Present ice cover of the Koryak mountain system]. Izvestiya Vsesoyuznogo Geograficheskogo Obshchestva [Newes of the All-Union Geographical Society], Tom 90 , Vyp. 6, 1958, p. 507-20. [282 small glaciers in Koryakskiy Khrebet on Pacific coast of Siberia.]

MARTIN, J. Note sur un phénomène électrique observé dans un puits de glace sur l'inlandsis groenlandais. Annales de Géophysique, Tom. 13, No. I, I957, p. 87-89. (Rapports scientifiques des Expéditions Polaires Françaises, N.II.3.) [Electrical phenomenon observed in 1949 in melt water pocket of Greenland glacier explained as manifestation of Workman-Reynolds effect.]

Mathews, W. H. Glaciological research in western Canada in 1957. Canadian Alpine Fournal, Vol. 41, 1958, p. $91-93$.

MAYR, A., and MOSER, R. Profilmessungen im Bereich der westlichen Dachsteingletscher. Zeitschrift für Gletscherkunde und Glazialgeologie, Bd. 4, Ht. 1-2, 1958, p. 1 30-36. [Table of sinking of ice surface and flow on lateral surface profiles on Grosser Gosau-Gletscher and Kleiner Gosau-Gletscher.]

MeLlor, M. Photogrammetric flow measurements on Antarctic glaciers. Transactions. American Geophysical Union, Vol. 39, No. 6, 1958, p. I1 58. [Short note on method used and results obtained.]

Merganton, P.-L. Un demi-siècle d'observations nivométriques dans les Alpes suisses. Bulletin de la Société Vaudoise des Sciences Naturelles, Vol. 67 (1), No. 297, 1958, rop. (Reprint.) [Snow depth measurements at Eismeer station and elsewhere in Swiss Alps, 1902-55.]

Mercanton, P.-L. Aires englacées et côtes frontales des glaciers suisses. Leurs changements de 1876 à 1934 d'après l'Atlas Siegfried et la Carte Nationale et quelques indications sur les variations de 1934 à 1957 . Cours d'Eau et Energie, 1958, No. 12, 7p. (Reprint.) [Analysis of retreat of Swiss glaciers based on maps.]

MorRIsOn, A. Circular crevasses, lakeless shores and rotating glaciers of the Homathko snowfield. Canadian Alpine Fournal, Vol. 41, 1958, p. 86-88. [Glaciological observations made during mountaineering expedition to British Columbia, 1957.] 
Müller, F. Eight months of glacier and soil research in the Everest region. Mountain World, r958/59 [pub. I958],
p. I9I-208. [Investigations on Khumbu Glacier, Siss p. I91-208. [Investigations on Khumbu Glacier, Swiss Mount Everest Expedition, I 956.]

Pillewizer, W. Neue Erkenntnisse über die Blockbewegung der Gletscher. Zeitschrift für Gletscherkunde und
Glazialgeologie, Bd. 4, Ht glaciers. English summary p. 32-33.]

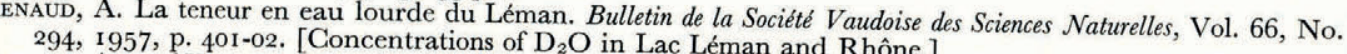

RENAUD, A., and HALLER, P. Société Helvétique des Sciences Naturelles, I 956 , p. 98-roo. [Quantitative de l'eau des bassins glaciaires. Actes de la $\mathrm{D}_{2} \mathrm{O}$ in glaciers and glacier run-off in Alps.]

Robin, G. DE Q. Glaciology. III. Seismic shootings and related investigations. Norzegian-British-Swedish Expedition, 1949-52. Scientific Results (Oslo, Norsk Polarinstitutt), Vol. 5, 1958, p. I-I 34 of investigations of thickness of ice sheet in Dronning Maud Land.]

Sharp, R. P. The latest major advance of Malaspina Glacier, Alaska. Geographical Review, Vol. 48, No. I, r958, p. 16-26. [Botanical and geological evidence of recent variations. Includes details of forest growing above
dead ice.]

Swrthinbank, C. W. M. Glaciology. I. The movement of the ice shelf at Maudheim. Norwegian-British-Swedish Antarctic Expedition, 1949-52. Scientific Results (Oslo, Norsk Polarinstitutt), Vol. 3, G, r958, p. 77-96. [At
approx. 7 $1^{\circ}$ S., I ${ }^{\circ}$ W. $]$ Wexler, H. Some aspects of Antarctic geophysics. Tellus, Vol. ro, No. I, 1958, p. 76-82. [General review of heat
and ice budgets of Antarctic ice sheet.]

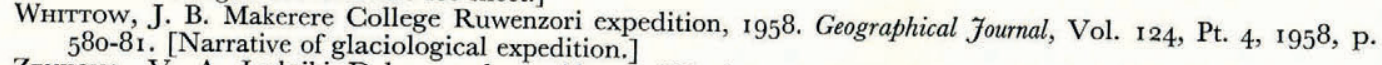

Zenkova, V. A. Ledniki Dzhungarskogo Alatau Kazakhstana [Questions of the Geography of Kazakhstan], Vyp of the Dzhungarskiy Alatau]. Voprosy Geografii

Zenkova, V. A. Sovremennoye oledeneniye v basseyne reki 3, r 959, p. I38-55. [Description.] [Present ice cover in the basin of the river Karatal'skaya Ki Karatal'skaya Kora v Dzhungarskom Alatau Kazakhstana [Questions of the Geography of Kazakhstan], Vyp.

Zubov, N. N. Predel'naya tolshchina materikazykhstan], Vyp. 3, I959, p. I 56-75. 1959, No. 3, p. 88-9o. [Theoretical statement of balance between ice thickness and heat flow from the earth.]

ICEBERGs. SEA, RIVER AND LAKe ICE

Anderson, D. L. Preliminary results and review of sea ice elasticity and related studies. Transactions of the Engineering Institute of Canada, Vol. 2, No. 3, 1958 , p. I $16-22$. [Methods of determining elastic properties of sea ice and results of static and dynamic tests, including determination of velocity of seismic waves.]

Anderson, D. L., and WeEks, W. F. A theoretical analysis of sea-ice strength. Transactions. American Geophysical Union, Vol. 39 , No. 4, 1958, p. $632-40$. [Theory of strength variation with salinity, temperature and density
and comparison with experiments.]

Armstrong, T. E. The recording and reporting of floating ice. Polar Record, Vol. 9, No. 60, I958, p. I84-90. [Systems in various polar seas by different nations.]

Armstrong, T. E. Sea ice north of the U.S.S.R. Part $I:$ frequency charts. Part $2:$ sources of information and their evaluation. London, Admiralty. Hydrographic Department, I958. 2 vols. (H.D. 5I.) [Summary of all available
information on distribution, presented cartographically.]

BARnEs, D. F. Preliminary measurements of the strength of melting lake ice. Transactions of the Engineering Institute of Canada, Vol. 2, No. 3, r958, p. ro8-1 I. [Tests on cantilever beams in situ on Angiussaq lake in Greenland.]

[BEARING STRENGTH OF FLOATING ICE.] Conference on the bearing strength of ice. Transactions of the Engineering Institute of Canada, Vol. 2, No. 3, 1958, p. 97-142. [Conference at Division of Building Research, National Research Council, Ottawa, i6-17 April 1958. Introduction by Robert F. Legget, 8 papers and discussion.]

Cherepanov, N. V. Opredeleniye vozrasta dreyfuyushchikh l'dov metodom kristalloopticheskogo issledovaniya

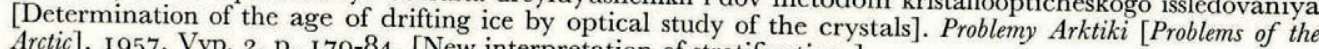
Arctic], r 957, Vyp. 2, p. 1 79-84. [New interpretation of stratification.]

Crary, A. P. Arctic ice island and ice shelf studies. Part I. Arctic, Vol. I r, No. 1, I958, p. 2-42. [General physical

characteristics of T-3 and of Ellesmere ice shelf: results of studies, r 952-55.]
GozDEcke, E. Neuere Untersuchungen über die Vorbereitungs- und Abschmelzzeit des Eises in der Deutschen Bucht und Westlichen Ostsee. Annalen der Meteorologie, Bd. 8, Ht. 3/4, 1957, p. 80-92. [Recent investigations into time of freezing and melting of ice in North Sea and Baltic.] Lebedev, V. L. Klassifikatsiya antarkticheskikh aysbergov [Classification of antarctic icebergs]. Problemy Severa
[Problems of the North], I958, Vyp. 2, p. 80-9o.

Loshchilov, V. S. Metod podvodnoy stereofotos"yemki v okeanograficheskikh issledovaniyakh [Method of submarine stereo-photography in oceanographical investigations]. Problemy Arktiki [Problems of the Arctic],
1957, Vyp. 2, p. 205-18. [Special reference to under surface of floating ice.]

LutkovskiY, S. V. Obrazovaniye l'da v ozerakh, rekakh $i$ moryakh [Formation of ice in lakes, rivers and seas]. Moscow, Izdatel'stvo Akademii Nauk SSSR [Publishing House of the Academy of Sciences of the U.S.S.R.], r957.
I 7 p.

Nusser, F. Zusammenhang zwischen Grosswetterlage und Eisvorkommen an den deutschen Küsten. Deutsche Hydrographische Zeitschrift, Jahrg. I 1, Ht. 5, 1958, p. 185-94. [Examination of weather records over 60 years indicates that east and north-east winds, together with high pressure over Fennoscandia produce conditions of maximum ice formation.]

Peschanskiy, I. S. O nekotorykh problemakh arkticheskogo ledovedeniya [Some problems of arctic glaciology]. 
Problemy Arktiki [Problem fthe Arctic], 1957, Vyp. 2, p. 161-70. [Physical properties of sea ice, particularly elasticity and reac on to deformation.]

SALA, I. Einige Messungen der Eisfestigkeit. Geophysica (Helsinki), Vol. 5, No. 3, 1957, p. 150-52. [Measurements of compressive strength of sea ice made at Helsinki, 1955-56.]

TновÉN, R. Fotografisk rekognoscering och tolkning av havsisen i Arktis. Ymer, Årg. 78, Ht. 4, 1958, p. 263-79. [Aerial photographic reconnaissance and interpretation of sea ice in Arctic; conditions and movements of sea ice in Arctic Ocean. English summary.]

Uusrtalo, S. Beobachtungen mit Bezug auf das Meereseis. Geophysica (Helsinki), Vol. 5, No. 3, 1957, p. 139-46. [Effect of salinity on growth of sea ice observed in Baltic.]

WeEKs, W. F., and ANDERson, D. L. An experimental study of strength of young sea ice. Transactions. American Geophysical Union, Vol. 39, No. 4, 1958, p. 641-47. [Results of cantilever beam tests.]

WEEKS, W. F., and LEE, O. S. Observations on the physical properties of sea ice at Hopedale, Labrador. Arctic, Vol. I I, No. 3 , 1958, p. I 34-55. [Preliminary results of field observations, 1955-56.]

\section{Glacial geology}

Bär, O. Gesteinsklüfte und Rundhöcker. Geographica Helvetica, [Vol.] 12, Nr. I, 1957, p. I-40. [Study of roches moutonnées and rock joints in the Aar and Gotthard massifs. Correlation of observed orientations.]

Bodvarsson, G. Geothermal effects of the Pleistocene glaciation in Iceland. Fökull, Ár 7, 1957, p. 1-20.

Cotton, C. A. Dissection and redissection of the Wellington landscape. Transactions of the Royal Society of New Zealand, Vol. 85 , Pt. 3 , 1958, p. 409-25. [Ice and postglacial action in forming geomorphology around Wellington.]

Fischer, I. The impact of the Ice Age on the present form of the geoid. Fournal of Geophysical Research, Vol. 64, No. I, I 959, p. 85-87. [Shape of geoid in North America shows remarkable correlation with extent of Pleistocene glaciation in these areas.]

GAMs, H. Staumäandermoore. Zeitschrift für Gletscherkunde und Glazialgeologie, Bd. 4, Ht. 1-2, 1958, p. 87-98. [Description of type of marsh caused by meandering in glacio-fluvial deposits of outflow from ice-dammed lakes.]

Godwin, H., and WILLIs, E. H. Radiocarbon dating of the late glacial period in Britain. Proceedings of the Royal Society, Ser. B, Vol. 150, No. 939, 1957, p. 199-21 5. [Upper and lower boundaries for cool temperature Allerød phase fall approximately at 8,800 B.C. and ro,00o B.C., while succeeding colder phase lasted until about 8,300 B.C., when ice retreat began.]

Paschinger, H. Las formas glaciares de la Sierra Nevada, Espana. Memorias y Comunicaciones del Instituto Geologico Provincial, Vol. 16, 1957, p. 81-86. [Post-Würm increase of ice cover.]

RukHina, YE. V. K voprosu o ponimanii termina morena [On the meaning attached to the term moraine]. Izvestiya Vsesoyuznogo Geograficheskogo Obshchestva [News of the All-Union Geographical Society], Tom 91, Vyp. I, I959, p. 82-84.

SchweIzer, W. Gletscherseen. Geographica Helvetica, [Vol.] 12, Nr. 2, 1957, p. 81-87. [Suggests classification of glacier lakes, both ice and moraine-dammed. English summary p. 87.]

Svensson, H. Morphometrischer Beitrag zur Charakterisierung von Glazialtälern. Zeitschrift für Gletscherkunde und Glazialgeologie, Bd. 4, Ht. I-2, 1958, p. 99-104. [Method for determining mathematically best parabola to fit to a valley cross-section and application to Lapporten valley, north Sweden.]

Svensson, H. Vertikal ismäktighet, återspeglad av lineära erosionshak i dalsidor. Svensk Geografisk Arsbok, Årg. 34, 1958, p. 181-82. [Measurement of former ice thickness by observation of linear erosion traces on sides of valleys.]

VEYRET, P. L'eau, la neige, la glace, le gel et la structure dans l'évolution morphologique de la région de Chamonix (Massifs du Mont Blanc et des Aiguilles Rouges). Revue de Géographie Alpine, Tom. 47, Fasc. 1, 1959, p. 5-36. [Relative importance of the various agents of erosion in the formation of topography of region.]

WolDstedt, P. Das Eiszeitalter: Grundlinien einer Geologie des Quärtars. Zweiter Band. Europe, Vorderasien und Nordafrika im Eiszeitalter. 2. Auflage. Stuttgart, Ferdinand Enke, 1958. vii, $43^{8}$ p. [Textbook on Quaternary geology. Former ice cover of Europe, Asia Minor and north and north-west Africa.]

Frost action on rocks and soll. Frozen ground. Permafrost

Соoк, F. A. Sorted circles at Resolute, N.W.T. Geographical Bulletin, No. I1, 1958, p. 78-81. [Canada. Patterned ground excavated 1955.]

Davies, J. L. The cryoplanation of Mount Wellington. Papers and Proceedings of the Royal Society of New Zealand, Vol. 92,1958 , p. $15 \mathrm{I}-54$. [Morphology due to frost shattering and periglacial processes generally.]

FitzPATRICK, E. A. An indurated soil horizon formed by permafrost. Fournal of Soil Science, Vol. 7, No. 2, 1956, p. 248-54. [Great Britain. Description of the features and a suggested cause of their formation.]

Frye, J. C., and Willman, H. B. Permafrost features near the Wisconsin glacial margin in Illinois. American Fournal of Science, Vol. 256 , No. 7, 1958, p. 518-24.

Twidale, C. R. Vallons de gélivation dans le centre du Labrador. Revue de Géomorphologie Dynamique, Année 9, Nos. $5-6,1958$, p. 84 . [Short note on further observations which confirm interpretation of these gullies as due to frost action as suggested in earlier paper, ibid., Année 7, Nos. 1-2, 1956, p. 17-23.]

\section{Meteorological aND Glimatological glaciology}

Rusis, N. P. Meteorologicheskiy rezhim antarkticheskikh oazisov i ikh vliyaniye na okruzhayushchuyu ledyanuyu poverkhnost' [Meteorological regime of antarctic oases and their influence on the surrounding ice surface]. Meteorologiya $i$ Gidrologiya [Meteorology and Hydrology], 1958, No. 3, p. 3-12. [Based on observations in and near "Bunger's Oasis", January 1957.] 
Schwerdtreger, W. Ein Beitrag zur Kenntnis des Klimas im Gebiet der Patagonischen Eisfelder. Zeitschrift für Gletscherkunde und Glazialgeologie, Bd. 4, Ht. 1-2, 1958, p. 73-86. [Estimation of climatic conditions in Patagonian ice fields. English summary, p. 85-86.]

YAKovLEv, G. N. Turbulentnyy teploobmen ledyanogo pokrova s vozdukhom v tsentral'noy arktike [Turbulent heat exchange between ice cover and air in the central Arctic]. Problemy Arktiki [Problems of the Arctic], 1957, Vyp. 2, p. 193-204. [Calculations based on observations at Soviet drifting station SP-2, 1950-51.]

\section{SNow}

Gunn, K. L. S., and Marshall, J. S. The distribution with size of aggregate snowflakes. Fournal of Meteorology, Vol. 15, No. 5, 1958, p. 452-61. [Measurements of size distribution in relation to rate of snowfall are discussed in relation to radar measurements of melting band.]

Rusin, N. P. Radiatsionnyy balans snezhnoy poverkhnosti v Antarktide [Radiation balance of snow surface in Antarctica]. Informatsionnyy Byulleten' Sovetskoy Antarkticheskoy Ekspeditsii [Information Bulletin of the Soviet Antarctic Expedition], No. 2, 1958, p. 25-30. [Results of observations at Soviet stations in 1956-57, Australian Antarctic Territory.]

Williams, G. P., and Gold, L. W. Snow density and climate. Transactions of the Engineering Institute of Canada, Vol. 2, No. 2, 1958, p. 9 I-94. [Data from selected stations in Canada: relationship between snow density and meteorological conditions; insulating value of snow cover in different regions.] 